- поглиблювати i розширювати знання студентів 3 народної творчості; підвищувати їх музичну культуру у процесі ознайомлення з особливостями музичнопоетичної мови, української народної інтонаційності, опанування навичками цілісного аналізу народних наспівів;

- відроджувати народні традиції та обряди в різних куточках краю; прищеплювати навички до збирання та систематизації фольклору (початок цьому дає фольклорна практика на II курсі), накопичення музичного матеріалу для подальшої роботи з дітьми.

Подальшу роботу спрямуємо на дослідження проблеми оволодіння майбутніми вчителями музики знаннями розвивально-терапевтичної функції українських дитячих музичних ігор.

1. Бондаревская Е. В. Гуманитарный статус личностно-ориентированного образования/ Евгения Васильевна Бондаревская// Славянская педагогическая культура. - 2007. - № 6. - С. 7-13. 2. Іваницький А. І. Український музичний фольклор : [підручник для вищих учбових закладів] /Анатолій Іванович Іваницький. - Вінниця : Нова книга, 2004. - 320 с. 3. Стельмахович М. Г. Українська родинна педагогіка : [навч.-метод. посібник] / Мирослав Гнатович Стельмахович. - К. : ICДО, 1996. - 288 с. 4. Ушинський К. Д. Вибрані педагогічні твори: у 2-х т./ Костянтин Дмитрович Ушинський. - Т. 1: Про користь педагогічної літератури. - К. : Рад. школа, 1983. - С. 926. 5. Щербак I. Діти в традиційних обрядах українців// Народна творчість та етнографія. - 2003. - № 3. - С. 71-77.

\title{
ФОРМУВАННЯ ІНФОРМАЦЙНОЇ КУЛЬТУРИ ПЕДАГОГА: ТЕОРЕТИЧНИЙ АСПЕКТ
}

Стукалова Т. Г. Формування інформаційної культури педагога: теоретичний аспект.

У статті розглядається вплив інформаційного суспільства на формування інформаційної культури вчителя. Проаналізовані структура та рівень сформованості інформаційної культури педагога, обгрунтована необхідність використання інформаційно-комунікаційних технологій на уроках, що забезпечують ефективність навчального процесу.

Ключові слова: інформація, інформатизація, інформаційна культура педагога, інформаційно-комунікаційні технології.

Стукалова Т. Г. Формирование информационной культуры педагога: теоретический аспект.

В статье рассматривается влияние информационного общества на формирование информационной культуры педагога. Проанализированы структура и уровень сформированности информационной культуры педагога, обоснована необходимость использования информационно-коммуникационных технологий на уроках, которые повышают эффективность обучающегося процесса.

Ключевые слова: информация, информатизация, информационная культура педагога, информационно-коммуникационные технологии. 
Stykalova T. G. The formation of a teacher's informational culture: theoretical aspect.

The article examines the influence of the informational society on the formation of a teacher's informational culture. The structure and level of informational culture of the teacher and the necessity of using information and communication technologies on the classes to ensure the effectiveness of the learning process are examined.

Key words: information, informatization, teacher's informational culture, information and communication technologies.

Інформатизація суспільства й комп’ютеризація всіх сфер людської діяльності стали провідними тенденціями світового розвитку. Інформаційно-комунікаційні технології все більше проникають у різні сфери життя, науки, освіти, виробництва, що вимагає відповідних знань та вмінь їх використовувати і цілеспрямованого формування інформаційної культури.

«Людина сьогодення постійно взаємодіє 3 величезним потоком інформації. Сучасне суспільство називають інформаційним. В інформаційному суспільстві найважливішим продуктом людської діяльності стає виробництво, експлуатація та використання знань, його головною цінністю стає інформація. Нині люди розуміють, що жодну серйозну економічну, соціальну, технічну задачу неможливо успішно розв'язати без перероблення значних обсягів інформації» [6, с. 124].

У зв'язку 3 цим важливого значення набуває вміння педагога доцільно використовувати у професійній діяльності сучасні надбання інформаційного суспільства.

Одним із важливих кроків модернізації освіти $\epsilon$ підготовка учнів до швидкого сприйняття й опрацювання великих обсягів інформації, озброєння їх сучасними засобами й технологіями роботи, формування в них інформаційної культури. Але відповідно, щоб сформувати інформаційну культуру в учнів, учитель і сам мусить володіти такою культурою.

Останніми роками більшість науковців підкреслюють важливість формування інформаційної культури, яка є складником загальної та фахової культури. Дослідження цієї проблеми знайшло відображення в доповідях та працях науковців сучасності: В. Бикова, М. Вохришевої, А. Гуржія, Н. Гендиної, Н. Зинов'євої, Н. Морзе, I. Моргенштерна.

«Інформаційна культура- один із складників загальної культури людини; сукупність інформаційного світогляду та системи знань і вмінь, що забезпечують цілеспрямовану самостійну діяльність за оптимального задоволення індивідуальних інформаційних потреб із використанням як традиційних, так і нових інформаційних технологій» [3, с. 110].

У сучасних психолого-педагогічних дослідженнях приділено увагу проблемі формування інформаційної культури. Питання визначення суті поняття культури та ії місця в освіті вивчали В. Андрущенко, А. Веряєв, Л. Губерський, Н. Крилова, В. Розін, I. Шалаєв.

Б. Гершунський, О. Готовцева, А. Єршова, М. Жалдак, Ю. Машбиця, В. Монахова, Н. Морзе, І. Пустинникова, М. Шкіль та інші науковці розглядали процес формування інформаційної культури майбутніх учителів i використання інформаційнокомунікаційних технологій у навчальному процесі.

Meта статmі: визначити структуру та показники сформованості інформаційної культури вчителя.

Аналіз праць науковців свідчить, що інформаційна культура педагога- це інтегроване особистісне утворення, що містить у собі не тільки вміння працювати 3 комп'ютером, а й уміння орієнтуватися в сучасному інформаційному середовищі, 
уміння шукати, відбирати і критично аналізувати інформаційні ресурси, уміння спілкуватися за допомогою сучасних засобів комунікації.

Отже, інформаційну культуру слід розглядати як досягнутий рівень організації інформаційних процесів, ступінь задоволення потреб людей в інформаційному спілкуванні, рівень ефективності створення, збирання, зберігання, опрацювання та використання інформації. Однією із ознак інформаційної культури особистості $є$ розуміння сутності інформаціі та інформаційних процесів, їх ролі у процесі пізнання довкілля дійсності та створюючої діяльності людини.

Учитель постійно працює 3 масивами інформації, що в сучасному суспільстві динамічно збільшуються. Надати правильну дидактичну оцінку інформаційної продукції здатна лише інформаційно грамотна особистість, тому закономірною $€$ необхідність підготовки вчителів до оволодіння педагогічними технологіями формування інформаційно грамотної особистості в сучасному постіндустріальному суспільстві, а для цього вони самі мають володіти високим рівнем інформаційної культури.

Інформаційну грамотність Р. Гуревич розглядає як «можливість особистості знаходити та використовувати інформацію з різних джерел» [4, с. 355].

Аналізуючи дослідження 3 розглядуваної теми, можемо виокремити основні компоненти інформаційної грамотності сучасного педагога: це вміння знаходити необхідну інформацію для професійної й повсякденної діяльності; користуватися цією інформацією, аналізувати, синтезувати, оцінювати іiі, використовуючи при цьому новітні інформаційні та комунікаційні технології.

Отже, інформаційна культура вчителя - це система інтеграційних взаємодій між розвитком інформаційної грамотності відповідно до сучасних досягнень науки і техніки, розвитком інформаційного досвіду, де головним критерієм $\epsilon$ певний рівень інформаційної компетентності спеціаліста.

На основі аналізу наукових джерел нами встановлено, що до структури інформаційної культури науковці відносять:

- когнітивну (знання і уявлення про нову інформаційну картину світу в гіпотезах і теоріях);

- операційно-змістову (практичні вміння і навички, пов'язані з одержанням, зберіганням, передаванням і обробленням інформації);

- комунікативну (принципи і правила поведінки особистості в інформаційних і комунікаційних системах);

- ціннісно-рефлексивну (життєві установки, оцінки і ставлення до інформаційної галузі) компоненти.

Усі згадані компоненти взаємопов'язані і взаємозумовлені.

Інформаційна культура вчителя, на думку І. Богданова, $\epsilon$ «відносно цілісною підсистемою загальної професійної культури людини, продуктом його творчих здібностей і в сукупності з професійно значущими якостями вчителя виявляється в таких аспектах», а саме:

- висока комунікативна культура;

- розуміння й уміння адекватно інтерпретувати тенденції розвитку інформаційного суспільства;

- володіння основами аналітичного перероблення інформації;

- уміння працювати з різною інформацією;

- знання особливостей інформаційних потоків у своїй сфері діяльності;

- ефективна робота з масовими інформаційними технологіями; 
- уміння отримувати інформацію з різних джерел та подавати іiі в зрозумілому вигляді;

- навички використання технічних пристроїв;

- володіння всіма жанрами навчально-методичної літератури;

- володіння засобами психолого-екологічного захисту від негативної інформації [1, с. 57].

Отже, інформаційна культура вчителя - це система знань, умінь і навичок із формулювання потреби в інформації; здійснення пошуку необхідної інформації з усієї сукупності інформаційних ресурсів; 3 відбору, оцінювання, збереження знайденої інформації; з інтеграції, структуризації і створення нової інформації.

Базуючись на дослідженнях Р. Гуревича, О. Сршова, М. Жалдака, С. Каракозова, виокремлюємо такі складники інформаційної культури:

- інформаційна компетентність: здатність забезпечити собі вільний доступ до інформації, створити і розповсюдити власну інформацію, ефективно використати знання в розв' язанні різних проблем;

- інформаційний ціннісно-змістовий компонент: система особистісно значущих і особистісно цінних устремлінь, ідеалів, переконань, поглядів, позицій у галузі інформаційних процесів;

- інформаційна рефлексія: відслідковування цілей, процесу та результатів своєї діяльності з присвоєння інформаційної культури, осмислення вчителем власного рівня інформаційної грамотності і компетентності;

- інформаційна культуротворчість: готовність вчителя до виконання культуротворчої ролі як стосовно присвоєння культури, так і створення нових форм культури.

Отже, формування і розвиток інформаційної культури вчителя, це не лише мета освіти, а й засіб, що дозволяє найбільш ефективно здійснювати освітні процеси. Розглядаючи інформаційну культуру як складник професійно-педагогічної культури вчителя, ми виходимо з того, що інформаційна грамотність і компетентність мають сприяти розвиткові його загальної культури, що містить у своїй структурі професійнопедагогічну.

На думку О. Значенко, інформаційна культура $є$ засобом соціального захисту особистості, здатної до самостійного накопичення знань, зміни сфери діяльності, регулювання особистої поведінки на основі всебічного аналізу ситуації. Інформаційна культура $є$ засобом захисту суспільства від непродуманих дій людини, гарантом того, що принципові рішення у будь-якій галузі - соціальній, економічній, технологічній приймаються лише після глибокого аналізу наявної інформації [5, с. 397].

Одним із компонентів інформаційної культури є формування вміння практичного використання комп'ютера у процесі власної навчально-пізнавальної і професійної діяльності.

Поняття «інформаційна культура» тісно пов’язане із дефініцією «інформаційна компетентність», яка становить компетентність індивіда в роботі з інформацією, а також комп’ютерну компетентність - уміння працювати з комп’ютером та IT [2, с. 12].

На наш погляд, інформаційна компетентність педагогів передусім передбачає їхню здатність використовувати апаратні засоби IT, а також ефективно працювати 3 інформацією в електронному i друкованому варіантах (швидко іiі знаходити та раціонально опрацьовувати).

Отже, компонентами інформаційної компетентності вчителя є: 
- технічний - характеризується знаннями архітектури персонального комп'ютера, характеристик базових і допоміжних периферійних пристроїв та вміння й навички їх використовувати;

- операційний - визначається знаннями характеристик операційних систем, їх призначення і складників частин, об'єктів, елементів управління та відповідними вміннями й навичками;

- програмний - передбачає оволодіння основами роботи зі спеціальним i загальним програмним забезпеченням;

- гігієнічно-ергономічний - санітарні умови і режими безпечного використання комп'ютерів і стандарти, яким повинна відповідати комп'ютерна техніка, що використовується в навчальному процесі;

- навчальний - оволодіння навчальними інформаційно-комунікаційними технологіями.

Отже, формування інформаційної культури педагогів - це насамперед формування системи знань, навичок і вмінь, необхідних педагогам для використання інформаційнокомунікаційних технологій у своїй професійній діяльності.

Виходячи 3 сучасних умов розвитку інформаційного суспільства і соціального замовлення, інформаційна культура вчителя сучасної школи передбачає сформованість:

- знань інформаційно-комунікаційних освітніх технологій;

- знань принципів побудови глобальної мережі та вміння використовувати іiі ресурси у професійній діяльності;

- умінь знаходити інформацію, аналізувати та диференціювати ії.

Інформаційна культура вчителя $\epsilon$ важливою у здійсненні педагогом своєї професійної діяльності, оскільки вимагає ефективно використовувати інформаційнокомунікаційні технології на уроках, що забезпечує ефективність навчального процесу.

\section{Література}

1. Богданова И. М. Формирование профессионально-педагогической готовности будущих учителей к компьютерному образованию школьников: дис...канд. пед. наук: 13.00.01. / И. М. Богданова. - Одес. пед. ин-т им. К. Д. Ушинского - Одесса, 1989. - 158 c. -2. Баловсяк Н. В. Історико-педагогічний аналіз виникнення поняття «інформаційна компетентність»/ Н. В. Баловсяк. - Дніпропетровськ, 2004. - Том 25. - С. 45. 3. Гендина Н. И. Информационная культура личности: диагностика, технология формирования [Текст]: учебно-метод. пособие: часть II / Н. И. Гендина, Н. И. Колкова, И. Л. Скипор. - Кемерово: Кемеровская гос. академия культуры и искусств, 1999. 146 с. 4. Гуревич Р. С. Формування інформаційної культури майбутнього фахівця / Р. С. Гуревич // Педагогіка і психологія професійної освіти: результати досліджень: зб. наук. праць / за ред. І. А. Зязюна, Н. Г. Ничкало. - К., 2003. - С. 354 360. - (Педагогіка і психологія професійної освіти: результати досліджень: зб. наук. праць). 5. Значенко О. П. Критерії сформованості компонентів інформаційної культури майбутніх учителів / О. П. Значенко // Збірник наукових праць Міжнародної науковопрактичної конференції «Підготовка майбутнього вчителя природничих дисциплін в умовах моделювання освітнього середовища». - Полтава, 2004. - С. 396-398. 6. Кремень В. Г. Освіта і наука в Україні - інноваційні аспекти. Стратегія. Реалізація. Результати / В. Г. Кремень. - К., 2005. - 448 с. 


\section{ФОРМУВАННЯ ГЕОГРАФІЧНИХ ПОНЯТЬ НА ОСНОВІ КОМПЕТЕНТНІСНОГО ПІДХОДУ ДО НАВЧАННЯ ГЕОГРАФІЇ УКРАЇНИ}

Тросюк С. Д. Формування географічних понять на основі компетентнісного підходу до навчання географії України.

У статті розкрито поетапність процесу формування географічних понять на основі компетентнісного підходу до навчання географії України. Подано структурні конструкти у змісті формування географічних понять у процесі навчання географії України на рівні явищ, відношень і понять. Наведено зразки завдань для формування географічної компетенції на засадах компетентнісного підходу.

Ключові слова: географічні поняття, компетентнісний підхід, учні основної школи, природничі предмети.

Тросюк С. Д. Формирование географических понятий на основе компетентностного подхода к обучению географии Украины.

В статье раскрыта поэтапность процесса формирования географичсеких понятий на основе компетентностного похода к обучению географи Украины. Приведены структурные конструкты в содержании формирования географических понятий в процессе обучения географии Украины на уровне явлений, отношений и понятий. Приведены примеры заданий для формирования географической компетенции на основе компетентностного подхода.

Ключевые слова: географические понятия, компетентностный подход, ученики основной школы, природоведческие предметы.

Trosyuk S. D. Formation of geographical concepts competency-based approach to learning geography of Ukraine.

The article deals with the gradual process of the formation of concepts geografichsekih competency-based education campaign to geographic Ukraine. The structural constructs in forming the content of geographical concepts in the process of learning ce geographic Ukraine at the level of phenomena, concepts and relationships. Are examples of exercises in order to create jobs geographical competence competency-based approach.

Key words: geographical concepts, competence-based approach, students osnvonoy schools, natural history items.

Реформування освіти в Україні є чинником здійснення процесів оновлення освітніх систем. Ці процеси відбуваються останнім часом у європейських країнах і пов'язані 3 визнанням значущості знань як рушія суспільного добробуту і прогресу. Тож на часі створення нових освітніх стандартів, оновлення і перегляд навчальних програм, змісту навчально-дидактичних матеріалів, підручників, а також удосконалення форм і методів навчання географії в основній школі.

Нагальним стає перегляд в основній школі змісту і відповідних стандартів на засадах досягнення конкретного результату, вираженого в термінах ключових i предметних компетентностей, оптимальна інтеграція, диференціація, індивідуалізація й інформатизація, методичне забезпечення загальноосвітніх навчальних закладів на основі використання компетентнісно орієнтованих технологій навчання.

Формування географічної компетенції учнів основної школи у процесі навчання географії України корелює із якістю набутої географічної освіти на основі 